Historic, archived document

Do not assume content reflects current scientific knowledge, policies, or practices. 



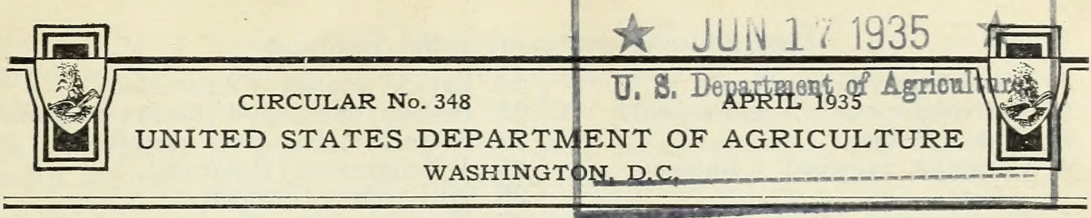

\section{QUAIL-FOOD PLANTS OF THE SOUTHEASTERN STATES}

By Alec C. Martin, junior biologist, Section of Food Habits, Division of Wildlife Research, Bureau of Biological Survey

\section{CONTENTS}

Page

Page

Introduction

Plant descriptions and comments

$$
\begin{aligned}
& \text { References... } \\
& \text { Illustrations. }
\end{aligned}
$$

\section{INTRODUCTION}

The Southeastern States form the heart of the range of the eastern bobwhite quail (Colinus virginianus virginianus). There this bird is most abundant, and there it is most hunted. There also, the greatest efforts are being made to preserve and increase the species.

The purpose of this circular is to facilitate recognition of the more important quail-food plants of the region and thus aid in fostering their production either in the wild or the cultivated state. The three main features of the publication are: (1) A list of the chief quail-food plants arranged in order of their use, (2) brief descriptive treatments of the various species, and (3) illustrations of 28 important plants and their seeds.

\section{RANKED LIST OF PLANTS}

The basic information for the evaluation of merit of quail-food plants has been obtained from records in the files of the Section of Food Habits, Division of Wildlife Research, Bureau of Biological Survey. Conclusions are based on data derived from the analysis of stomach and crop contents of more than 2,000 bobwhites taken in all months in the Southeastern States. The data represent the findings of a number of investigators from 1900 to 1934 but the chief contribution was made by Herbert L. Stoddard and Charles O. Handley in recent (1924-29) studies in connection with the cooperative quail investigation.

Forty-six food items are listed, the relative position of each being determined by the percentage it constituted in the total bulk of food present in the stomachs of the birds examined. The ranking is not necessarily final; furthermore some of the items rated comparatively low may be of much importance in certain localities, at particular seasons, or in connection with special phases of the bobwhite's life history. The list as here presented, however, should be instructive in indicating the relative extent of actual use of various food plants by the bobwhite. 


\section{Food preferences of quail in the Southeast}

1. Bushclovers (Lesvedeza).

2. Partridge-peas (Chamaecrista).

3. Pines (Pinus).

4. Common ragweed (Ambrosia elatior).

5. Beggarweeds (Meibomia).

6. Oaks (Quercus).

7. Milk peas (Galactia).

8. Corn (Zea mays).

9. Cowpeas (Vigna); soybeans (Soja).

10. Sumacs (Rhus).

11. Wheat (Triticum).

12. Hogpeanut (Falcata comosa).

13. Black locust (Robinia pseudoacacia).

14. Snapweeds (Impatiens).

15. Paspalum grasses; sideseed grasses (Paspalum).

16. Sweetgum (Liquidambar styraciflua).

17. Grapes (Vitis).

18. Dewberries; blackberries (Rubus).

19. Wild cherries (Padus).

20. Bayberries; waxmyrtles (Myrica).

21. Flowering dogwood (Cynoxylon floridum).

22. Wild beans (Strophostyles).

23. Smartweeds (Polygonum).
24. Bristle grasses (Chaetochloa).

25. Sesban; danglepod (Sesban emerus).

26. Sassafras (Sassafras sassafras).

27. Witchgrasses (Panicum).

28. Nut sedges (Scleria).

29. Huckleberries (Gaylussacia); blueberries (Vaccinium); deerberries (Polycodium).

30. Tupelos; black gums (Nyssa).

31. Crabgrasses (Syntherisma).

32. Violets (Viola).

33. Hollies (Ilex).

34. Bluecurls (Trichostema dichotomum).

35. Buttonweed (Diodella teres).

36. Poison-ivy (Toxicodendron).

37. Peanut (Arachis hypogaea).

38. Blueweed (Echium vulgare).

39. Butterfly-pea (Bradburya virginiana).

40. Sorghum (Holcus sorghum).

41. Beautyberry (Callicarpa americana).

42. Morning-glories (I pomoea et al.).

43. Stingnettle (Tragia).

44. Sheep sorrel; dock (Rumex).

45. Mexican-clover (Richardia scabra).

46. Vetches (Vicia).

\section{PLANT DESCRIPTIONS AND COMMENTS 1}

\section{BUSHCLOVERS; LESPEDEZA}

(Fig. 1, $A$ and $B$ )

There are six or more kinds of bushclovers (lespedezas) native or naturalized in the Southeast. All species are eaten by quail, but the one generally termed lespedeza (Lespedeza striata) is outstanding in value and is commonly planted on quail preserves. It is an introduced annual, usually a low, spreading plant, and in favorable situations reseeds itself readily. L. frutescens and L. violacea are important native forms and, like most of the other species, are erect perennials, usually 1 to 3 feet high. Bushclovers are characterized by white, pink, or purplish flowers and are distinct from beggarweeds in having small, short pods, which are not several-jointed and do not cling readily to clothing. Some of the seeds tend to persist on the plants into the winter months.

\section{PARTRIDGE-PEAS}

(Fig. 1, $C$ and $D$ )

Fifteen species of the genus Chamaecrista occur in the Southeast, but only two, C.fasciculata and C. procumbens, are of known importance to quail. They are exceptionally popular sources of quail food. The plants have bright yellow flowers, stand about 2 feet high, and occur isolated or in extensive dense growths, and in such stands furnish excellent cover as well as much good food. C. fasciculata has larger flowers and much longer flower stems and pod stems than C.procumbens.

\section{PINES}

(Fig. 2, A)

Pine mast is consumed by quail freely when available, but usually the trees seed heavily only at intervals of several years. Loblolly

1 Numerous contributions and annotations by Herbert L. Stoddard, of Sherwood Plantation, Thomasville, Ga., by Wallace B. Grange, of Ephraim, Wis., and by F. V. Coville, of the Bureau of Plant Industry, are gratefully acknowledged. Small's Manual of the Southeastern Flora, 1933, has been used as a standard of technical nomenclature, except in the genera Myrica, Rumex, Polygonum, Gaylussacia, and Vaccinium. 
pine (Pinus taeda) and longleaf pine (P. australis) are probably used more than other species, but slash pine ( $P$. caribaea) and yellow pine, or shortleaf pine ( $P$. echinata), also rank high. Quail seem to be especially partial to the seeds of longleaf pine, but the supply from loblolly pine is more dependable.

\section{RAGWEED}

(Fig. 2, B)

Common ragweed (Ambrosia elatior) is an abundant annual weed of grainfields, clearings, and roadsides and is one of the most important of all quail foods in fall and early winter, especially in the Piedmont. The height of the plants is variable but usually ranges between 1 and 3 feet; the leaves are grayish green and much divided. Ragweed volunteers in almost all rich soils that are disked or plowed between October 1 and March 1 . The giant, or big, ragweed $(A$. trifida) is used comparatively little in the Southeast, probably because it is not nearly so prevalent as the common ragweed.

\section{BEGGARWEEDS}

(Fig. 2, C)

Species of the genus Meibomia are numerous. The plants are mainly upright and bushy, usually several feet high, and have small purple or pink flowers and flat fruit pods, which disjoint into segments and cling to clothing. The seeds mature late and are available for fall and winter use. Probably all species are useful and valuable; $M$. purpurea, $M$. dillenii, and $M$. obtusa are known to be important quail foods. At present only the seed of $M$. purpurea can be purchased readily; this species is planted extensively in light soils on quail preserves of the Gulf and South Atlantic States.

\section{OAKS}

(Fig. 2, D)

In some years acorns form one of the most important sources of food supply for quail. The species with small acorns, such as willow oak, or pin oak (Quercus phellos), and water oak (Q. nigra), seem to be preferred. Probably red oak (Q. rubra) and live oak (Q. virginiana) are used considerably. Other common oaks of the region also have some value, and the leaves of some of these are illustrated in outline.

\section{MILK PEAS}

(Fig. 3, A)

Fourteen species of milk pea (Galactia) are listed for the Southeast, several of them restricted to Florida. Only two, G. volubilis and $G$. regularis, are recognized as important. Where milk peas are plentiful, quail have shown a decided partiality for their beanlike seeds. They are mostly sprawling vines of sandy soils with three-foliate leaves and pink, purple, or white flowers.

\section{CORN}

Standing corn (Zea mays) supplies a very favorable food for quail. The combination of corn and weeds furnishes good protective cover and excellent food.

\section{COWPEAS; SOYBEANS}

Bobwhites are partial at times to cowpeas (Vigna) and soybeans (Soja). In the warmer, humid parts of the Southeast, only mildewresisting varieties of cowpeas, such as Iron and Brabham, should be planted for quail. 


\section{SUMACS}

(Fig. 3, B)

Only two species of sumac (Rhus) are of significance as quail food in the Southeast: Dwarf, or black, sumac (R. copallina); and smooth, or white, sumac ( $R$. glabra). The former can readily be distinguished by the wing-margined midrib of its leaf. Both species are shrubs or shrubby trees, common along roadsides, ditches, and clearings. They produce large clusters of tart, red, berrylike fruits, which are available for quail practically every month of the year.

\section{WHEAT}

Wheat (Triticum) gleanings are in themselves an important quail food, and the unplowed stubble fields serve as ideal situations for the growth of the common ragweed (Ambrosia elatior).

\section{HOGPEANUT}

(Fig. 3, C)

Hogpeanut (Falcata comosa) thrives in rich, moist woodlands. It is a slender, climbing, perennial vine having three-foliate leaves, and small white to purple flowers and clusters of short pods.

\section{BLACK LOCUST}

(Fig. 3, D)

The black locust (Robinia pseudoacacia) is a tree with rough bark, spiny twigs, compound leaves, and pendant clusters of fragrant white flowers, which later are replaced by dry pods. Its natural distribution in the Southeast is restricted largely to the vicinity of the mountain area, but it is frequent elsewhere as a shade tree. Black locust should not be confused with the less useful honeylocust (Gleditsia triacanthos), which has numerous long, branched thorns and bears broad, twisted pods, often a foot or more long.

14. SNAPWEEDS

(Fig. 4, A)

Snapweeds, or touch-me-nots (Impatiens biflora and I. pallida) are smooth herbs with watery semitransparent stems; I. biflora with orange-colored flowers and $I$. pallida with yellow. They are less common in the Coastal Plain than in the Piedmont and mountain areas, where they thrive in moist, shaded places, particularly along streams.

\section{PASPALUM GRASSES; SIDESEED GRASSES}

(Fig. 4, $B$ and $C$ )

There are 33 species of Paspalum recorded for the Southeastern States. Bull grass (also called water grass) ( $P$. boscianum) is one of the most important foods of young quail late in summer and in fall. It is abundant in some cultivated fields in the Coastal Plain and in many places volunteers freely when the ground is disked or plowed in spring. $P$. floridanum and $P$. setaceum are used considerably. The inflorescences of paspalums have one to several flattened, one-sided branches to which the grains are closely attached. The grains are flattish on one side and rounded on the other and vary in outline from broadly oval to nearly circular. 


\section{SWEETGUM}

(Fig. 4,D)

Sweetgum, often called red gum (Liquidambar styraciflua), is a common tree and often abundant in bottom lands. Its star-pointed leaves, corky twigs, and pendant, many-horned, spherical fruits are distinctive. The winged seeds are a popular fall food for the bobwhite but appear to be available for only a short season following the first hard frosts.

\section{GRAPES}

(Fig. 5, $A$ )

There are many species of wild grapes (Vitis) and the most important as quail foods have not been determined. $V$. cordifolia and $V$. vulpina are probably valuable because of their prevalence and also because of their late ripening. Where they flourish in woods and along streams, the vines furnish good refuge cover as well as food.

\section{DEWBERRIES; BLACKBERRIES}

(Fig. 5, A)

The species of Rubus are numerous. R. trivialis is the abundant southern dewberry of fields and waste places. Thickets of the vines provide food for spring and summer and also afford valuable cover.

\section{WILD CHERRIES}

(Fig. 5, B)

Five species of wild cherry (Padus) are found in the Southeast. Wild blackcherry ( $P$. virginiana) and chokecherry $(P$. nana) are the most common; the former is a medium-sized or large tree, and the latter a shrub or small tree. Quail use both the fresh and dried fruits, and, in spring, the germinating seeds.

\section{BAYBERRIES; WAXMYRTLES}

(Fig. 5, C)

Of the four species of bayberries in the Southeast, Myrica cerifera and $M$. carolinensis are the most important. They are one of the main sources of winter food in parts of the Coastal Plain.

\section{FLOWERING DOGWOOD}

(Fig. $5, D$ )

The flowering dogwood (Cynoxlyon floridum) has some value for winter feeding because of its prevalence, but while many quail learn to eat its fruit, the habit is by no means general in all coveys. Even in the absence of the showy, white flower bracts or the clusters of bright red fruits, flowering dogwood can be easily identified by the checkered pattern of its bark - similar to the markings of persimmon trunks but shallower.

\section{WILD BEANS}

(Fig. 6, A)

There are three species of wild bean in the Southeast, two of which, Strophostyles helvola and S. umbellata, are useful as quail food. They are twining or trailing beanlike vines of sandy soils. 


\section{SMARTWEEDS}

(Fig. 6, B)

By some authors, including Small, the large group of smartweeds is divided into several genera, including Persicaria (smartweeds), Polygonum (knotweeds), Tracaulon (tearthumb), and Bilderdykia (cornbind). In this study it will be convenient to use Polygonum in the inclusive sense.

Fifteen smartweeds are listed for the Southeast. One of them is aquatic but probably the others are all more or less useful to quail. Polygonum pennsylvanicum has been found frequently in quail stomachs. On the whole smartweeds are much more important in the North than in the South. They are generally smooth plants of moist or swampy places, with rather long leaves and clusters of heads of small pink or white flowers in which are borne the black or darkbrown seedlike fruits.

Knotweeds and tearthumbs are of minor importance. Cornbind, also called wild buckwheat or black bindweed ( $P$. convolvulus), is used considerably. It is a vine somewhat resembling the bindweeds of the morning-glory family but is unrelated to the latter and is distinct in its small, inconspicuous flowers and triangular seeds.

\section{BRISTLE GRASSES}

(Fig. 6, C)

There are nine species of bristle grass, or pigeon grass (Chaetochloa), in the Southeast. $C$. lutescens and $C$. viridis are common in fields and open waste places in the Piedmont and are probably the species most important for quail. The genus is characterized by bushy or bristly spikelike inflorescences.

\section{SESBAN; DANGLEPOD}

(Fig. 6, D)

Sesban, or danglepod (Sesban emerus), is a smooth, upright, bushy annual, 4 to 12 feet high, with compound leaves bearing 10 to 35 pairs of leaflets. The flowers are usually yellowish, spotted with purple, and are replaced by long, flat, narrow pods, 6 to 12 inches long and segmented by partitions between the seeds. The plant is restricted to moist soils, and quail appear partial to it in localities where it is abundant. As the seeds are easily harvested in quantity, it shows much promise of usefulness on quail preserves.

\section{SASSAFRAS}

(Fig. 7, A)

Sassafras (Sassafras sassafras) is a common, small or medium-sized tree, with greenish twigs, simple or lobed leaves, and red-stemmed blue fruits. The latter appear to be very useful to bobwhites.

\section{WITCHGRASSES}

(Fig. 7, $B$ and $C$ )

Species of the grass genus Panicum are very numerous, and Small lists 117 in the Southeast. Among the most abundant and most available to quail are $P$. dichotomiflorum, $P$. verrucosum, $P$. neuranthum, $P$. anceps, and $P$. scoparium. The group is too heterogeneous to be characterized easily. The grains are generally flattish on one side and rounded on the other and are ordinarily more elongated and more pointed than the closely related paspalums. 


\section{NUT SEDGES}

(Fig. 7, D)

Fifteen species of nut sedges (Scleria) occur in the Southeast. They are slender, upright plants, usually 1 or 2 feet high, with three-angled stems, flat grasslike leaves, and small clusters of comparatively large, bony, white, ovoid or globular nutlets. They are common in low pinelands and are eaten frequently by quail.

\section{HUCKLEBERRIES; BLUEBERRIES; DEERBERRIES}

Species of the shrubby huckleberries (Gaylussacia), blueberries (Vaccinium), and deerberries (Polycodium) are rather numerous over the Coastal Plain, Piedmont, and mountain areas. Though no special ones are recognized as outstandingly important, probably any kind is valuable that is locally abundant and bears considerable fruit.

\section{TUPELOS; BLACK GUMS}

There are six species in the Nyssa group, four of which are trees. The black gums ( $N$. sylvatica and $N$. biflora) are fairly important in supplying food for quail. The former species has several fruits in a cluster and grows in both upland and lowland situations; the latter usually has but two fruits in a cluster and is restricted to swampy places. Tupelo (N. aquatica), another swamp or river-margin species, is used occasionally by quail. It is a tall tree with broad, severaltoothed leaves and large solitary fruits. The fruit of Nyssa is a drupe, or stone fruit, usually dark blue and having a large, ridged stone.

\section{CRABGRASSES}

Eleven species of the crabgrass group (Syntherisma) occur in the South, six of them restricted to Florida. The most common are $S$. sanguinale and S. ischaemum. They are low annuals, with long, slender inflorescence branches radiating from a common axis and bearing tiny, closely attached grains. Crabgrasses are abundant in fallow fields, and while they appeared frequently in the quail stomachs examined, their total bulk in the diet is inconsiderable.

\section{VIOLETS}

Forty-one species of violet (Viola) are listed for the South, and probably all are more or less useful as quail food. When available, entire capsules containing seeds are freely consumed by quail.

\section{HOLLIES; ILEX}

Nineteen species of holly (Ilex) occur in the South. Probably gallberry ( $I$. glabra) is the only one of any importance as a quail food, though the fruits of several species are used occasionally. Gallberry is common in the coastal flatwoods, where it forms a large part of the winter or early-spring food supply. Male and possibly some female trees of the common American holly (I. opaca) fail to produce berries, so that at least double the number of bearing trees desired should be planted. Yaupon, or cassena (I. vomitoria), is common along the coast, but it is used by quail comparatively little.

\section{BLUECURLS}

Bluecurls (Trichostema dichotomum) is an erect, branching annual, averaging about 1 foot high and having four-angled stems, smooth- 
margined, opposite leaves, and blue flowers, with conspicuous, longextended, upwardly curled, violet-colored stamens. It is a common plant of dry soil in open fields or woods, and its seeds are often found in quail stomachs, though usually in small quantities.

\section{BUTTONWEED}

Buttonweed (Diodella teres) is a low, rather wiry, branching annual with rough, spreading branches, opposite, narrow leaves, and small pink flowers, solitary in the leaf axils. It is one of the most prevalent weeds in the South and frequently occurs in quail stomachs though it is relatively unimportant because of the small bulk consumed. The flat side of the dry, seedlike fruit shows some resemblance in form to the bottom of a horse's hoof. Fields, roadsides, and open waste places afford this plant an ideal environment.

\section{POISON-IVY}

Poison-ivy and oakleaf poison-ivy (Toxicodendron) are vines or shrubs with three-foliate leaves and clusters of round, whitish, berrylike stone fruits. Bobwhites consume the fruits without apparent harm, and under certain conditions the shrubby plant plays an important part in the winter food supply.

\section{PEANUT}

Quail are very fond of peanuts (Arachis hypogaea) and glean them from harvested or hogged-off fields. Cultivation of the plant is restricted largely to sandy or sterile soils of the Coastal Plain.

\section{BLUEWEED}

Blueweed (Echium vulgare) is a bristly-hairy plant of fields and waste places, 1 or 2 feet high, having numerous, medium-sized flowers, pink in bud and blue when open. The nutlets are large, rough, and three-angled.

\section{BUTTERFLY-PEA}

The butterfly-pea (Bradburya virginiana) is a twining vine of sandy soils with three-foliate leaves, long, pointed pods, and showy, lavenderpink flowers. It is a preferred quail food where it occurs but is more important in the Coastal Plain than elsewhere.

\section{SORGHUM}

Some stomach records indicating sorghum (Holcus sorghum) were excluded because of questionable determination, and it is possible that this plant is considerably more important than the present ranking indicates. It is an important bobwhite food in Oklahoma and the Southwestern States, where it is often planted on preserves. The variety known as "Egyptian wheat" is one of the best for quail because the inflorescence is loose and the grains are therefore less susceptible to molding.

\section{BEAUTYBERRY}

Beautyberry, or French-mulberry (Callicarpa americana), is a shrub with large, smooth-margined, opposite leaves and showy clusters of small, globular, lavender-purple fruits. It is a popular source of food from late summer until frost and is probably more 
abundant and more important in the Coastal Plain than elsewhere. It grows chiefly in sandy soils.

\section{MORNING-GLORIES}

Many kinds of morning-glory, particularly of the genus Ipomoea, are found in the Southeast. In some fields they are abundant enough to be valuable as quail food.

\section{STINGNETTLE}

Six species of stingnettle (Tragia) occur in the Southeast, where they are prevalent in sandy soils. T. urens is used as a quail food. The plants are erect or reclining perennials, with alternate leaves that are usually coated with stinging hairs. Their fruits are dry capsules containing three globose, mottled or spotted seeds.

\section{SHEEP SORREL; DOCK; AND OTHER GREEN-FOOD PLANTS}

Sheep sorrel, or field sorrel (Rumex acetosella), is a common perennial weed with soft, arrow-shaped, acid-tasting, basal leaves. The stems are slender, several inches to a foot or more high, often reddish in color and having close clusters of small flowers and dry fruits. The latter are eaten freely, but the main value of the plant lies in its usefulness as green food. In this respect it shares importance with clover (Trifolium), chickweed (Alsine), Mexican-clover (Richardia scabra), and woodsorrel (Xanthoxalis). Other species of Rumex are of minor importance as quail food.

\section{MEXICAN-CLOVER}

Mexican-clover (Richardia scabra) is a common southern annual, similar to its sprawling relative buttonweed (Diodella teres), but distinct in having the flowers clustered and mainly terminal. Bobwhites use the leaves for green food and eat the seeds to a limited extent.

\section{VETCHES}

Quail eat the seeds of cultivated vetches (Vicia) readily in localities where the crop is raised. The plants mature in spring, when the seeds of other legumes may be scarce.

\section{REFERENCES}

Persons or organizations interested in the efficient development of quail preserves or in the improvement of quail ranges will find useful information in the final report ${ }^{2}$ of the 5 -year cooperative quail investigation conducted by the Bureau of Biological Survey and a committee of sportsmen. It is available at a nonprofit price through special arrangement with the Quail Study Fund Committee. The address of the publishers may be obtained from the Bureau of Biological Survey. Also there is available a directory of dealers in quail-food plants.

\section{ILLUSTRATIONS}

In the illustrations that follow, the plant parts other than seeds are reduced to half or quarter natural size. The scale of magnification of seeds is with few exceptions indicated. The drawings were made by the author from living and pressed material and from photographs.

${ }^{2}$ STODDARD, H. L. THE BOBWHITE QUAIL: ITS HABITS, PRESERVATION, AND INCREASE. 559 pp., illus. New York, 1931. 

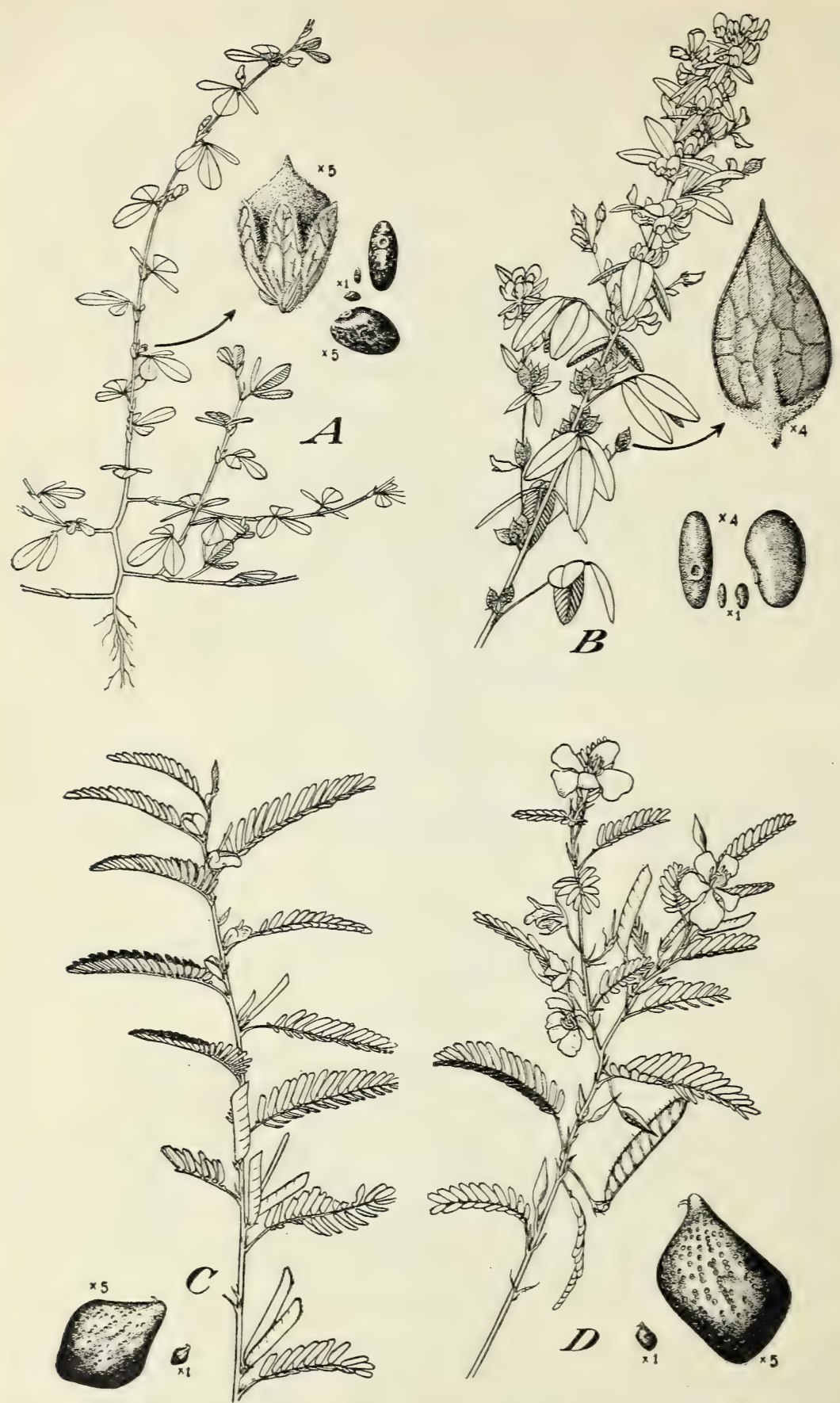

Figure 1.-A, Bushclover, or lespedeza (Lespedeza striata); B, bushclover (L. frutescens); C, partridge-pea (Chamaecrista procumbens); $D$, partridge-pea (C. fasciculata). 


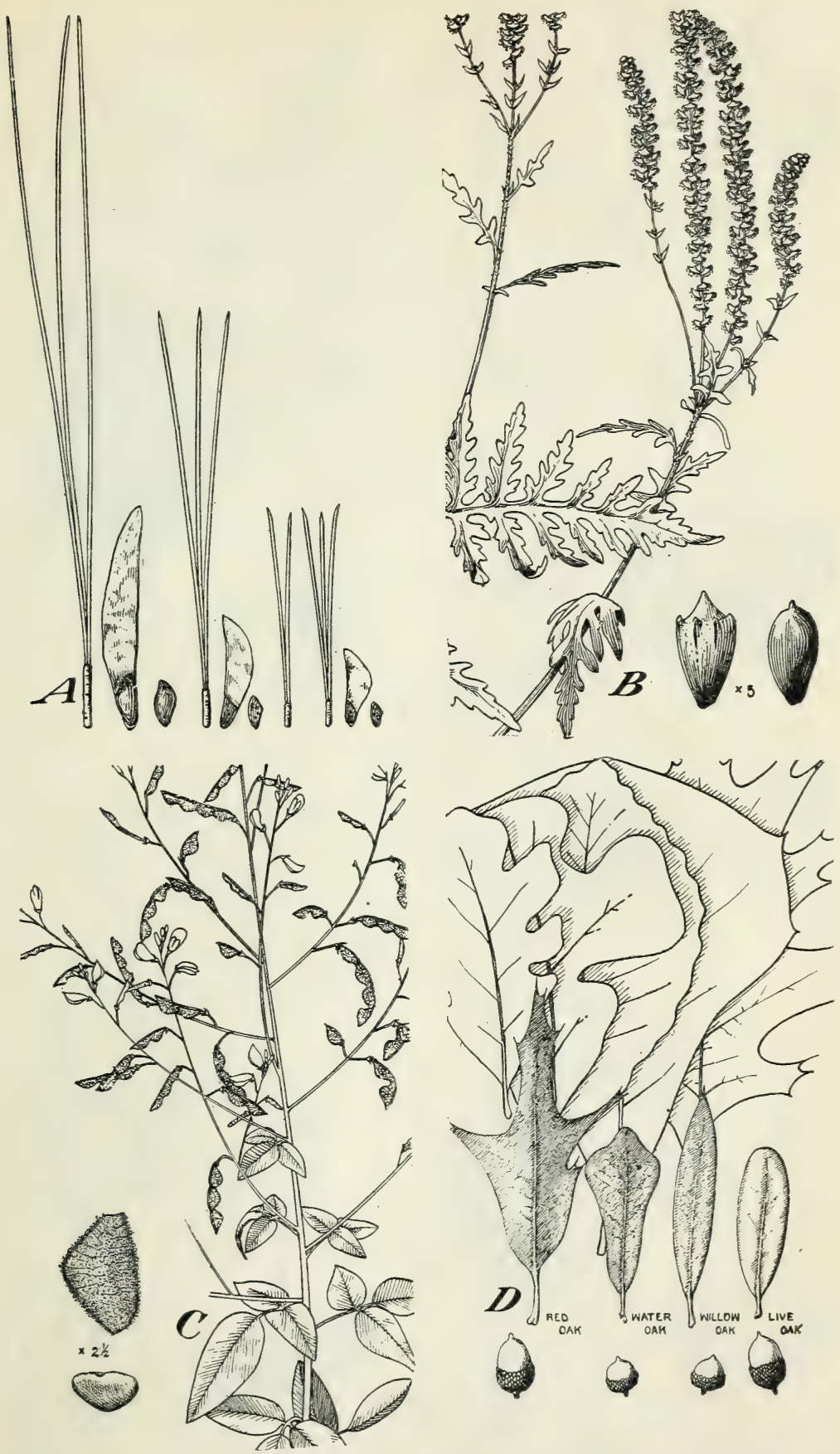

FIGURE 2. $A$, Longleaf, loblolly, and yellow pine leaves and seeds; $B$, common ragweed ( $A$ mbrosia elatior); $C$, beggarweed (Meibomia dillenii); $D$, leaves and acorns of oaks. 

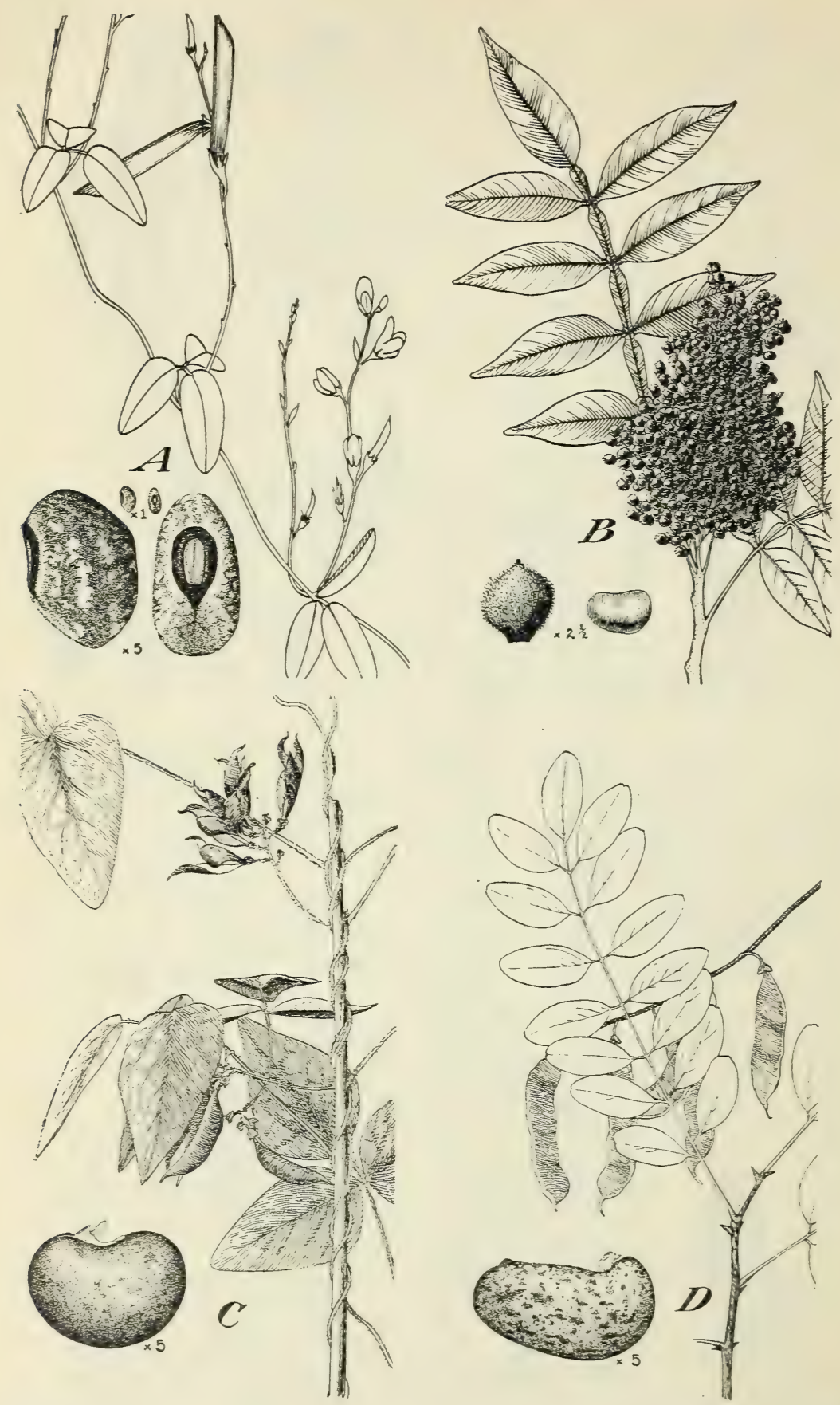

FIGURE 3.-A, Milk pea (Galactia volubilis); B, dwarf, or black, sumac (Rhus copallina); C, hogpeanut (Falcata comosa); D, black locust (Robinia pseudoacacza). 

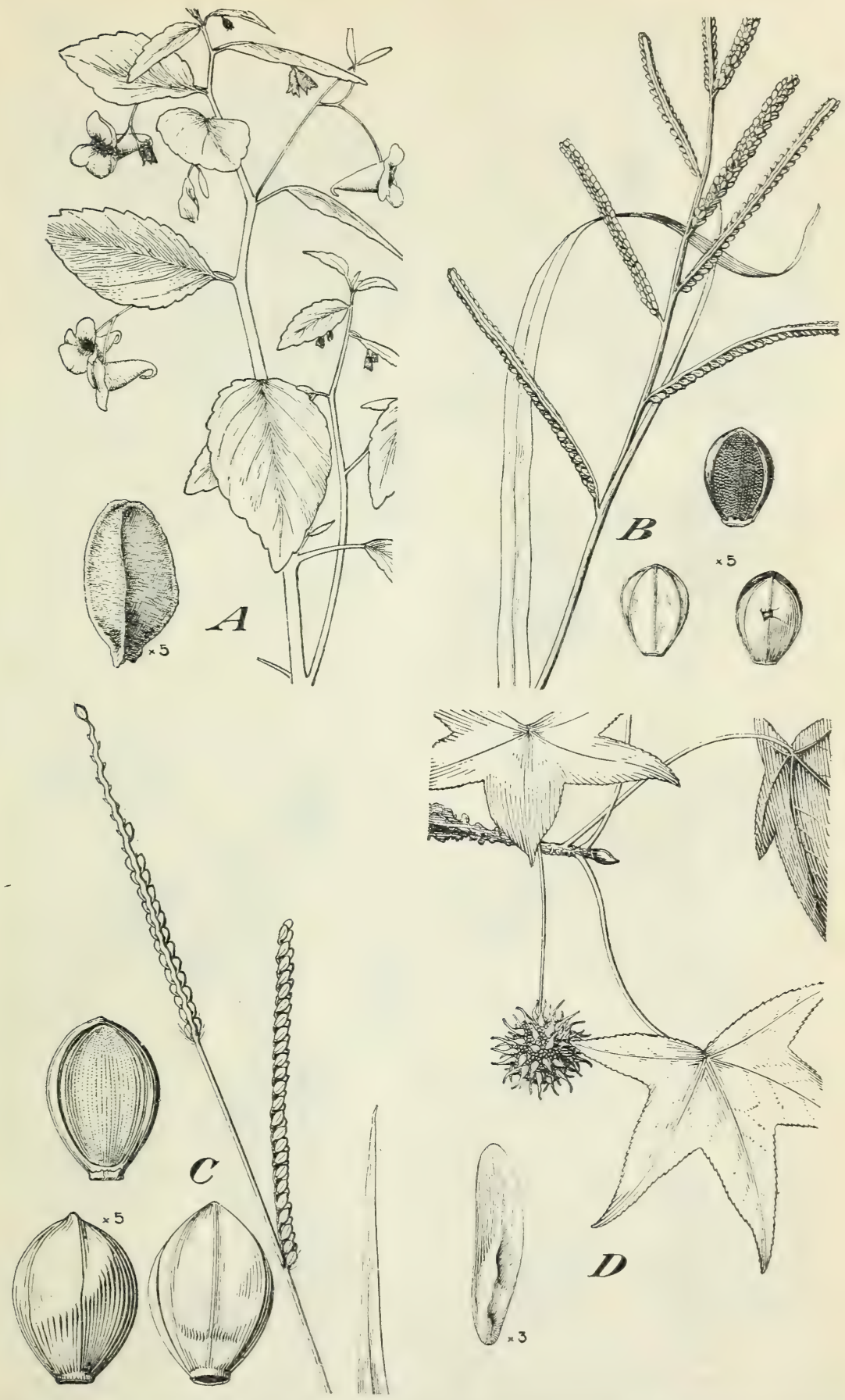

FIGURE 4.-A, Snapweed (Impatiens biflora); B, bull grass (Paspalumboscianum); C, Paspalum floridanum); $D$, sweetgum (Liquidambar styraciflua). 

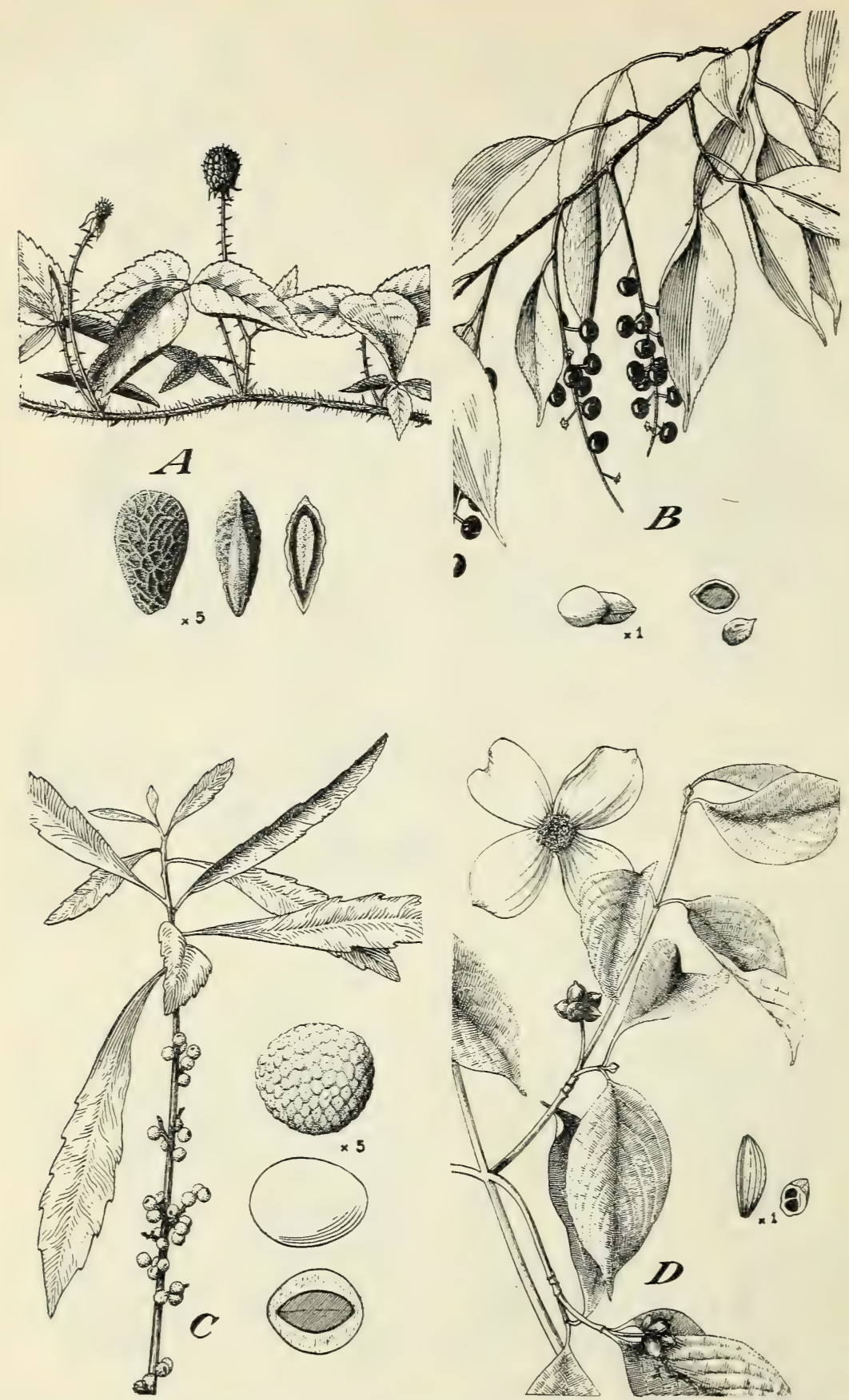

Figure 5.-A, Dewberry (Rubus trivialis); $B$, wild blackcherry (Padus virginiana); $C$, bayberry (Myrica cerifera); $D$, flowering dogwood (Cynoxylon floridum). 

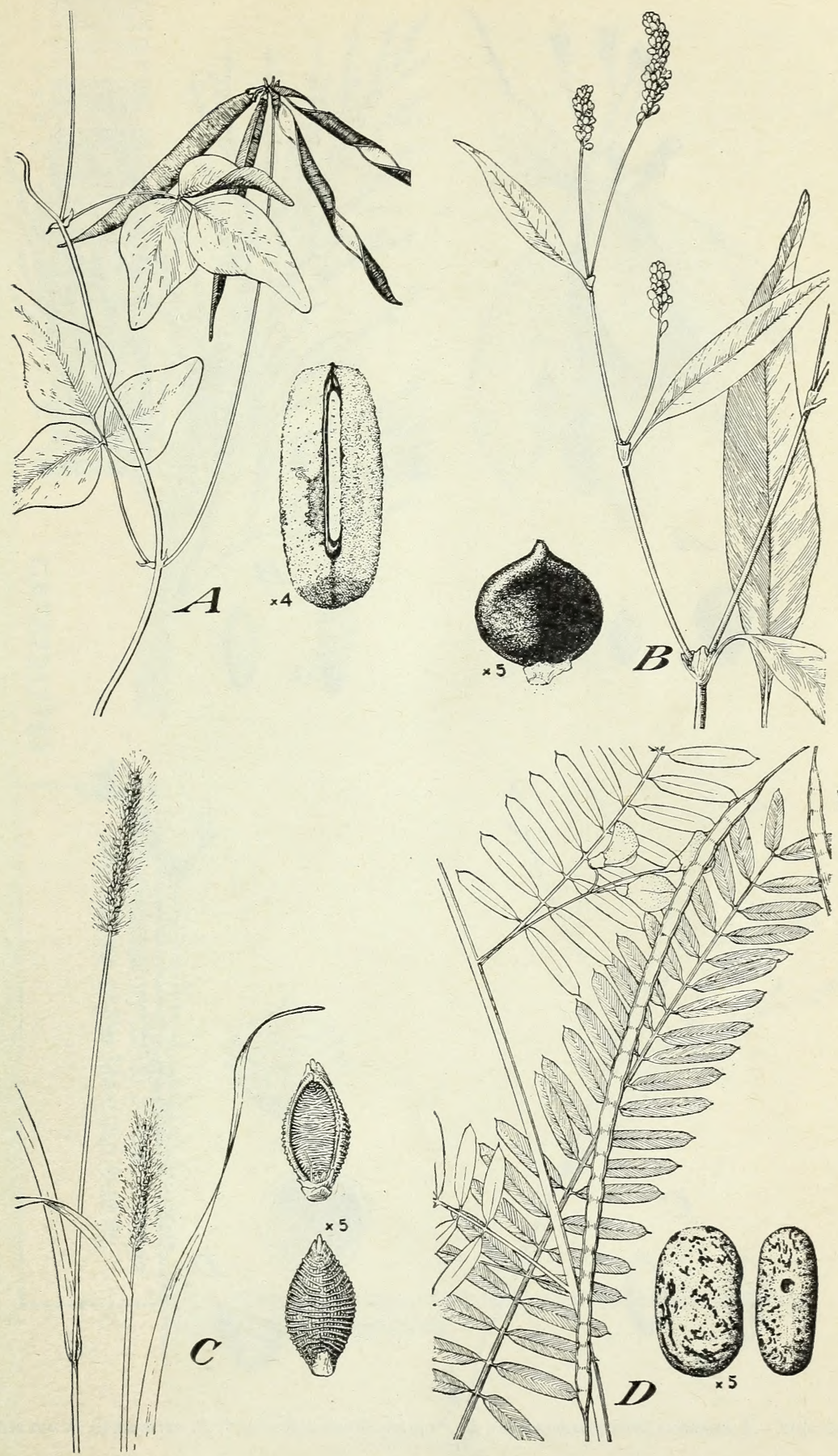

Figure 6.-A, Wild bean (Strophostyles helvola); B, smartweed (Polynonum pennsylvanicum); $C$, bristle grass (Chaetochloa lutescens); D, sesban, or danglepod (Sesban emerus). 

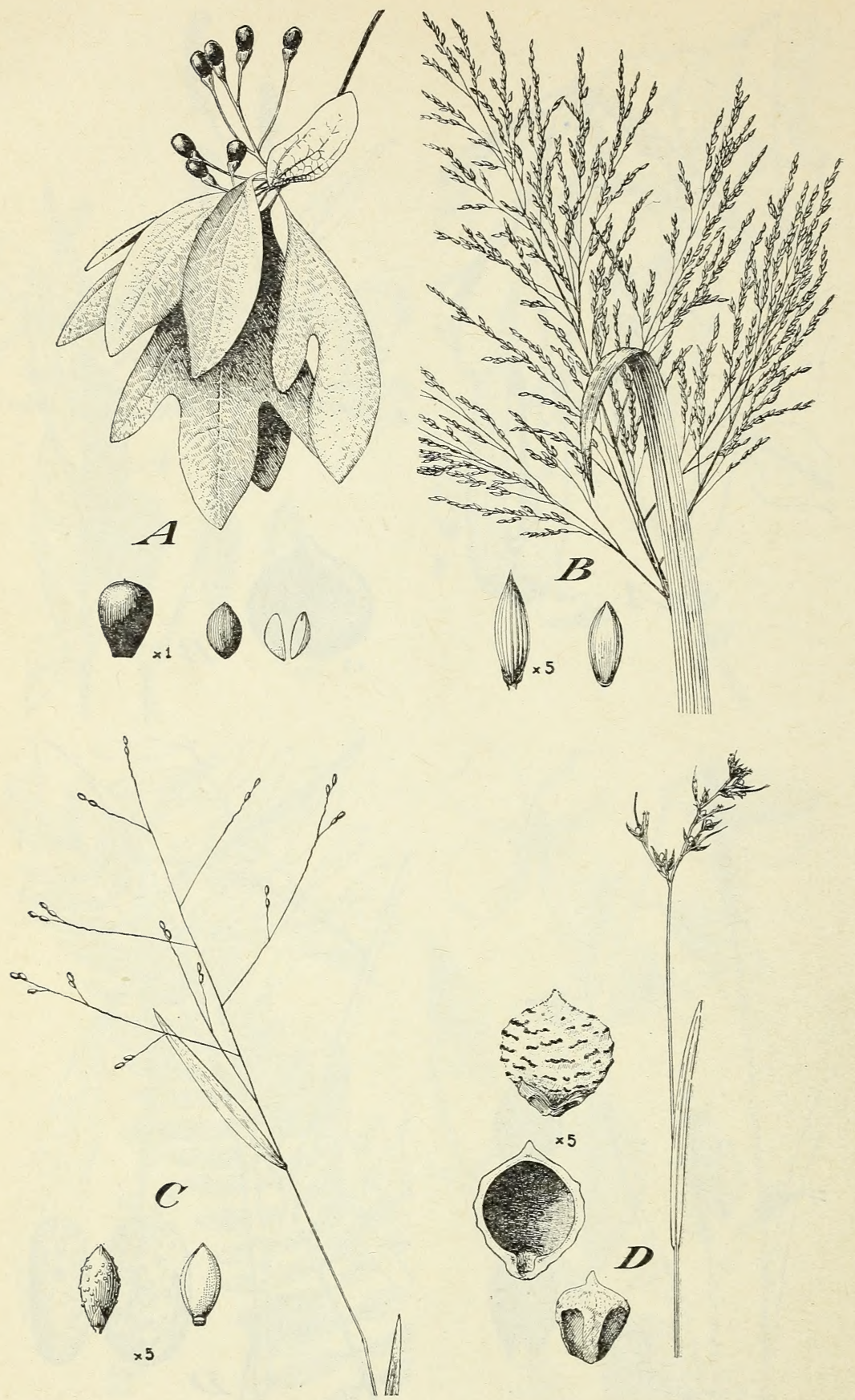

Figure 7.-A, Sassafras (Sassafras sassafras); B, Panicum dichotomiflorum; C, P. verracosum; D, nut sedge (Scleria setacea).

U. S. GOVERNMENT PRINTING OFFICE: 1935 

